This is an electronic reprint of the original article. This reprint may differ from the original in pagination and typographic detail.

Author(s): Nie, Dan; Lämsä, Anna-Maija

Title: $\quad$ The Leader-Member Exchange Theory in the Chinese Context and the Ethical Challenge of Guanxi

Year: $\quad 2015$

Version:

Please cite the original version:

Nie, D., \& Lämsä, A.-M. (2015). The Leader-Member Exchange Theory in the Chinese Context and the Ethical Challenge of Guanxi. Journal of Business Ethics, 128(4), 851861. https://doi.org/10.1007/s10551-013-1983-9

All material supplied via JYX is protected by copyright and other intellectual property rights, and duplication or sale of all or part of any of the repository collections is not permitted, except that material may be duplicated by you for your research use or educational purposes in electronic or print form. You must obtain permission for any other use. Electronic or print copies may not be offered, whether for sale or otherwise to anyone who is not an authorised user. 
The Leader-Member Exchange Theory in the Chinese Context and the Ethical Challenge of Guanxi

Dan Nie

dan.nie@jyu.fi

School of Business and Economics

P.O.Box 35, University of Jyväskylä

FI-40014, Jyväskylä, Finland

Anna-Maija Lämsä

anna-maija.lamsa@jyu.fi

School of Business and Economics

P.O.Box 35, University of Jyväskylä

FI-40014, Jyväskylä, Finland 


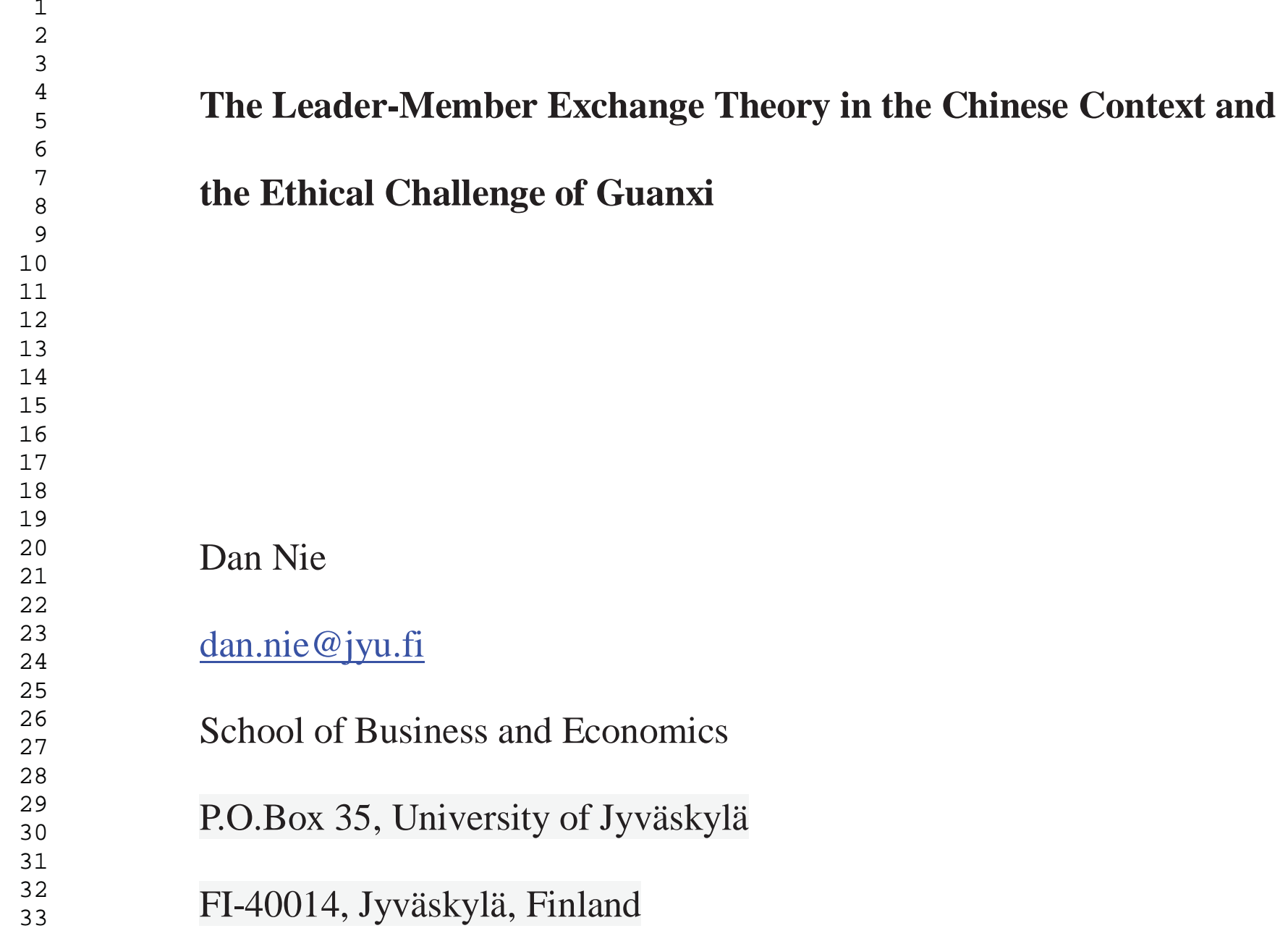

\section{The Leader-Member Exchange Theory in the Chinese Context and the Ethical Challenge of Guanxi}

Dan Nie

dan.nie@jyu.fi

School of Business and Economics

P.O.Box 35, University of Jyväskylä

FI-40014, Jyväskylä, Finland

\author{
Anna-Maija Lämsä \\ anna-maija.lamsa@jyu.fi \\ School of Business and Economics \\ P.O.Box 35, University of Jyväskylä \\ FI-40014, Jyväskylä, Finland
}


The Leader-Member Exchange Theory in the Chinese Context and the Ethical Challenge of Guanxi

\begin{abstract}
.
The leader-member relationship has been identified as a key determinant of successful working relationships and business outcomes in China. A high quality leader-member relationship helps managers and employees to meet the demands they face and gives them the opportunity to develop socially, emotionally and morally. Such relationships form the basis of the overall well-being and success of the organisation. This article contributes to relationally oriented leadership theories and more specifically to the leader-member exchange (LMX) theory by examining the theory in the context of Western expatriate managers and Chinese employees in China. The first aim of the study is to analyse the similarities and differences between the LMX theory, which owes its origins to Western corporate experience, and the social and moral norms of guanxi, a crucial element in the Chinese value system. Since Westerners and Chinese people can give different interpretations to guanxi, the second aim of the article is to discuss the ethical challenges to the Western manager arising from guanxi. The findings of this study have implications not only for China, but also for other Chinese communities (Macau, Taiwan, Hong Kong, the Philippines, and Singapore) where guanxi is endorsed and practised.
\end{abstract}

KEY WORDS: Leader-member relationship, LMX, leadership, values, ethics, Confucianism, guanxi, China 


\section{Introduction}

The significant economic changes in China in recent years have led to a surge of interest in the Western business world in increased co-operation with China. One key factor in business success in the Chinese context for expatriate managers from the West is the development of constructive relationships with the local Chinese staff with whom they are working (Economist intelligence Unit, 1996; Law et al., 2010). A high quality relationship helps managers and employees meet the demands they face and gives them the opportunity to develop socially, emotionally and morally (Uhl-Bien, 2006). Such a relationship is also the basis of the overall well-being and success of the organisation.

Since the relationship between a manager and a subordinate is known to be critical in determining outcomes at work (Brower et al., 2000; Uhl-Bien, 2006), Western expatriate managers have been under increasing pressure to build up and maintain effective and sustainable relationships with local Chinese employees. One particular leadership theory, the leader-member exchange theory, known as LMX, which emphasises the importance of relationships, can be useful in the Chinese context (Redding \& Wong, 1986; Yang, 1993; Hui \& Graen, 1997). According to the LMX theory, the higher the quality of leader-member relationship between the manager and his / her subordinates, the more positive the effect on work will be (Gerstner \& Day, 1997; Cogliser et al., 2009). The LMX theory is probably among the relational leadership frameworks that is best known to Western managers nowadays (Cogliser et al., 2009; Ladkin, 2010; Dulebohn et al., 2011; Walumbwa et al., 2011).

However, the LMX theory is a globally promoted construct that has its origins in Western corporate experience. Directly transplanting the ideas of the theory as practised 
by many multinational or Western managers to a Chinese context may not produce a good cultural fit, and this might make development of the leader-member relationship difficult. In line with Ciulla (2008), we argue in this paper that leadership as a human phenomenon is embedded in culture. Culture affects leadership in ways that are not readily apparent. Therefore, the question of how to apply the ideas of LMX in the context of Chinese culture becomes very important for Western managers who take local values seriously. Without an understanding of local values, it is difficult for Western managers to overcome cultural barriers and build constructive and nourishing leader-member relationships with local employees (Chen \& Chen, 2004; Ladkin, 2010).

One of the most important elements of Chinese social values, guanxi, was chosen for this study. Guanxi highlights the importance of the particular relationship between two parties (Chen \& Chen, 2004; Chen \& Tjosvold, 2007; Huang \& Wang, 2011), such as the leader-member relationship between a manager and a subordinate, and shares many things in common with the LMX theory. However, although it is one of the key factors in successful leadership in China, the role of guanxi and the subtleties of the concept may not be familiar to Westerners. We therefore take as our first aim in this study an analysis of the similarities and differences between the LMX theory and the social and moral norms of guanxi. By comparing the traditional Confucian value system in China and specifically the related ideas of guanxi with the LMX theory, we hope to show Western expatriate managers how they can successfully build effective and sustainable leader-member relationships with local employees in China. Finding shared meanings and values in leadership allows people to work together in productive and potentially harmonious ways (Ladkin, 2010). 
Prior research shows that Western and Chinese people understand guanxi differently (Chan et al., 2002; Su et al., 2003; Verhezen, 2008). Westerners tend to view it as unethical behaviour (Chan et al., 2002), whereas to Chinese people guanxi is an inherent part of their work ethic, and a critical and ethical way of acting in Chinese organisations (Su et al., 2003). In order to make guanxi and its ethical challenges clearer to Western managers, our second aim in this paper is to identify and discuss the ethical challenges posed by guanxi in the leader-member relationship between a Western manager and local staff and consider what the westerner needs to take into consideration in the Chinese work context. One question is how to use this more personal and less transactional approach properly and ethically. The results of this discussion may also have implications for Westerners working in other Chinese communities (Macau, Taiwan, Hong Kong, the Philippines, and Singapore) where guanxi is endorsed and practised.

The article is structured as follows. First of all we clarify and analyse the background and development of the LMX theory. Then, basing our discussion on an analysis of Confucianism and its moral rules for social conduct, we discuss guanxi. Next, we explore the similarities and differences between the ideas of the LMX theory and guanxi and consider what Western managers need to pay attention to in practice in order to build effective leader-member relationships with Chinese employees. We then discuss the ethical challenges that practising guanxi presents to Western managers. Finally, we offer our suggestions and present our conclusion.

\section{Background and Development of the LMX theory}

The LMX theory is interested in the work relationship that is formed between the leader 
and the follower. Initially, the theory was called the Vertical Dyad Linkage (VDL) model and was developed over 30 years ago (Graen, 1975). The LMX theory is based on the principle that each leader-follower relationship within a work group is unique and varying in quality (Anand et al., 2011). According to the theory, relationships and work roles are developed or negotiated over time through a series of various interactions between the leader and the follower that defines the different types of relationships: low quality and high-quality relationships (Bauer \& Green, 1996). Low LMX relationships are characterised by economic exchange based mainly on formal and tangible assets, such as employment contracts and payment (Blau, 1964; Dulebohn et al., 2011), whereas people in high-quality relationships will get far more than those in low relationships, not only in terms of economic exchange, but also in social exchange; more specifically, such values as mutual trust, obligation, respect, loyalty and reciprocity will become the dominant features in the relationship (Liden \& Maslyn, 1998; Uhl-Bien \& Maslyn, 2003).

The LMX theory is rooted in two main theories: role theory (Graen, 1976; Dienesch \& Liden, 1986; Graen \& Scandura, 1987; Sparrowe \& Liden, 1997) and social exchange theory (Wayne \& Green, 1993; Erdogan \& Liden, 2002). In the LMX theory, there are three elements: the leader, the follower, and the exchange relationship (Graen \& Uhl-Bien, 1991). Although leaders are dominant in determining the quality of LMX relationships, followers also exert a remarkable influence on the relationship. Through various and effective activities during working time, participants are supposed to meet certain objectives, fulfilling expectations and and creating reciprocal relationships.

Role theory argues that in an organisational setting, each participant has a role to play, and each accomplishes their work through these roles (Graen, 1976). This 
emphasises the nature of people as social actors who learn behaviours appropriate to the roles they occupy in their social environment (Solomon et al., 1985). That is the foundation of LMX. The degree to which employees comply with task demands and demonstrate their trust- worthiness dictates the type of LMX relationship that forms (Liden \& Maslyn, 1998). Graen and Scandura (1987) theorise that the quality of the leader-member relationship develops over a series of steps in which individuals "test" one another. To conceptualise how a high-quality work relationship can be developed, Graen and his colleagues suggested a role-taking, role-making, and role-routinisation process (Graen, 1976; Graen \& Scandura, 1987).

Prior research has suggested that leaders and followers have different expectations of each other (Xu et al., 2011). For example, Chinese employees usually expect a leadership style where the leader maintains a harmonious relationship with followers while being directive (Hsu, 1982), whereas employees from Western Europe, Scandinavian countries and North America, characterised by high individualism, tend to support participative management processes (Hofstede, 1980; Smith \& Peterson, 1988; Dorfman et al., 1997).

In order to set up an outstanding image and meet with employees' expectations, the first step for a leader is to get to know and understand employees' expectations towards him or her. After the role-taking phase, relationship development enters the role-making phase. It is a process of clarifying each other's expectations. At this stage leaders listen and seek clarification, they do not argue or get defensive, and it will be helpful for them to spend necessary time to talk with subordinates. This process occurs over time, and defines the quality and maturity of a leader-member exchange (Graen, 1976; Graen \& 
Uhl-Bien, 1995). After the development phase, the behaviours of a leader and followers are more predictable than before. Regardless of whether the relationship develops into high-quality exchanges, a set pattern of normative behaviours or role-routinisation occurs (Graen \& Scandura, 1987; Sin et al., 2009). Leaders in this stage have constructed good interaction with in-group members characterised by mutual trust and obligation through the allocation of resources and the distribution of important tasks.

Social exchange processes fostering relationships between leaders and followers are characterised by generalised reciprocity (Liden et al., 1997) or mutual-interest reciprocity (Uhl-Bien \& Maslyn, 2003) as argued in social exchange theory on LMX (Graen \& Uhl-Bien, 1991; Wayne \& Green, 1993; Erdogan \& Liden, 2002). In contrast with economic exchange, Blau (1964, p. 99) argued that "only social exchange tends to engender feelings of personal obligation, gratitude, and trust; purely economic exchange as such does not." This distinction between social and economic exchange is fundamental to the way in which low and high exchanges have been distinguished in LMX research (Sparrowe \& Liden, 1997). The social exchange creates a felt obligation on the part of organisational members to reciprocate their leaders' trust and liking through "citizenship behaviours" and good performance (Gerstner \& Day, 1997).

According to social exchange theory, LMX is by nature an exchange theory of leadership (Brower, 2000), thus the norm of reciprocity (Gouldner, 1960) between the leader and the follower is its central feature (Cropanzano \& Mitchell, 2005). In order to create a reciprocal relationship during working time leaders and followers can perform activities like making offers, inducements and provisions on the exchange process to achieve their objectives and become interrelated. If one person accepts an offer from 
another, and reciprocates a satisfactory response, the process continues in this way, resulting in high-quality relations over time (Cogliser et al., 2009). Employees who feel that they benefit from their leader will try to reciprocate by offering a favour in return (Xu et al., 2011). Therefore, a leader can take advantage of this phenomenon by doing a favour ahead of the employees, such as volunteering to give more resources or offering professional support and rewards, to encourage employee work performance. Employees who receive more resources from their leader will become more committed and will be more inclined to reciprocate naturally, and this will further promote the development of high-quality leader-member relationships (Cogliser et al., 2009). After receiving employees' favours, what is important for leaders is to prepare to extend a new favour next time, for example, using their power to collect as many new resources and as much useful information as possible. Moreover, providing timely development in professional areas related to daily work are sensible and practicable activities for leaders to engage in.

\section{Chinese values}

Confucianism

The Chinese historical and socio-cultural context is deeply rooted in the Confucian value system, in particular, that of hierarchy and relationalism (Yang, 1993). Feudalism has played a major role in the history of China. From 475 BC to the Revolution of 1911, feudal society has a history of about 2400 years. During this long history, Confucianism occupied a dominant position, always influencing social life, economics, politics, and especially the ideology embedded in people's minds. Based on an ethics of harmony and respect building the society of ancient China, the collection of important interpersonal 
relationships has been stressed and valued by Confucianism. The collection of relationships is called "wu lun", a concept widely and rigorously governing traditional Chinese moral behaviour (Law et al., 2010). The literal term wu means five; lun refers to the paramount importance of human relationships and moral principles regarding the interactive behaviours of related parties. In relationships, a social order, which can be called hierarchical differentiation (Chen \& Chen, 2004), is crucial. According to Confucianism, emperor-subject, father-son, husband-wife, elder-younger siblings, and friend-friend are the five most important interpersonal relationships (Hui \& Graen, 1997; Chen \& Chen, 2004; Law et al., 2010). The hierarchy stems from the five cardinal relationships, and refers to the moral principle of respecting superiors (Chen et al., 2011). With the exception of the relationship between friend and friend, the other relationships require that people in lower positions should give respect to people in higher positions in social intercourse. Thus, traditionally, it is natural for Chinese people to obey and follow this moral norm of respecting people higher in the social hierarchy as well as to develop psychological and behavioural tendencies which favour an authoritarian orientation (Yang, 1993).

According to Yang (1993), the Chinese tend to be highly sensitive to authority and worship it in many different forms. If the Chinese view an authority, for example, leaders in organisations, as trustworthy, they will be completely dependent upon those authorities and become totally obedient. Although the structural make-up and the nature of the relationship may have evolved since the time of Confucius, modern Chinese remain oriented towards authoritarian relationships in their attitudes and behaviour (Redding \& Wong, 1986; Wang \& Heller, 1993). Specifically, when it comes to the relationships 
between managers and employees, the Confucian value of hierarchy and authoritarian orientation still has a significant influence on people. It is specifically the positional power managers possess in the hierarchy that influences employee behaviour (Hwang, 2000; 2008). Following this line of thought, Chen et al. (2001) argue that the more positional power a person in leadership has, the more authority she or he presents, and the more obedience employees will show. Although findings by Peng et al. (2001) show that in general the higher the pressure from an individual in a leadership position, the lower the willingness of employees to engage in extra-role behaviours, Chinese people respect authority associated with hierarchical positions. Even though they may experience negative emotions under authoritarian leadership, their level of trust in the leader remains intact. Thus, in this culture with its greater power distance, individuals are more likely to regard leadership as the controlling of resources for accomplishing tasks and the application of power for rewards and punishments (Aryee \& Chen, 2006). A leader who has more resources and power, generally speaking, will get a higher evaluation from followers than leaders who have fewer resources and power.

\section{Chinese guanxi}

Belonging to a group is of central importance in Confucian thinking. In other words, according to Confucian values, individuals cannot exist without membership in a group. Guanxi is one of the most important elements of Confucianism highlighting the significance of groups for individuals. Traditional and contemporary Chinese are well-known for their strong reliance on interpersonal relations as the basis for defining their social status (Yang, 1993). Just as a popular Chinese saying goes "Whom you know 
is more important than what you know", Chinese often view themselves as interdependent with the surrounding social context, and it is the self in relation to the other that becomes the focal individual experience (Tsui \& Farh, 1997).

An interpersonal relationship, in the Chinese language, is called guanxi. The term can be used as both a verb and a noun. As a verb it means to have bearings on; as a noun it denotes a state in which entities (objects, forces or human beings) are connected (Chen \& Chen, 2004). A common explanation of guanxi is that it is a highly particularistic relationship between two parties, which can vary in magnitude and direction (Hui \& Graen, 1997). Personal guanxi is like a private channel through which people communicate and exchange (Hackley \& Dong, 2001; Chen \& Chen, 2004). Guanxi is built upon a mutually recognized "guanxi base" (Tsang, 1998, p. 65) or common ground. Commonly, the guanxi base may be a kinship relation (Tong \& Yong, 1998; Fan, 2002), which represents inherited guanxi, or some social interconnections (Dunfee \& Warren, 2001) such as a shared birthplace, a shared neighbourhood or workplace, or a shared acquaintance with whom both people have guanxi (Yeung \& Tung, 1996; Chen \& Chen, 2004). The latter must be cultivated and developed through the exchange of gifts, favours, and banquets (Smart, 1993) to build trust and credibility.

When it comes to the value of guanxi in China, researchers are split between true believers and sceptics. Believers share the Chinese conviction that guanxi is an important predictor of business success in China, and that individuals who enjoy close relations will feel enough trust to engage in open-ended and long-lasting relationships (Wu et al., 2006). Sceptics, on the other hand, think that although guanxi may indeed be quite important for the Chinese, it just does not work well for Westerners: it certainly does not help them 
very much, and it may even cause them problems. Previous studies have been primarily concerned with the purely instrumental dimension and pragmatic use of guanxi and have paid little attention to its constructive effect (e.g, Farh et al., 1998; Xin and Pearce, 1996).

In this article we have adopted the idea that guanxi plays an important role in China and that Westerners working in China need to take it into consideration (Chan et al., 2002; Su et al., 2003). Guanxi can be regarded as the glue that holds Chinese society together (Lovett et al., 1999). As Hui and Graen contend (1997, p. 454): “Guanxi as an important construct in China is evident not only in terms of the specific role definition of the wu lun, but the role it plays in defining the infrastructure of the Chinese society." Understanding and learning to build high-quality guanxi in China is not only helpful in terms of personal connections but also in terms of success at work. Those with personal guanxi are accorded a high level of trust and respect and to them people sense some kind of obligation, but those who do not share the common personal guanxi are easily excluded from the social network (Chen \& Tjosvold, 2007).

At the organisational level in China, guanxi with government officials protects the business from arbitrary government action (Pearce, 1997). It is also considered to be a strategic resource, a substitute for formal institutional support for organisational leadership, facilitating desirable business results (Xin \& Pearce, 1996; Tsang, 1998; Chen \& Tjosvold, 2007). At the individual level, guanxi is thought to be a key factor in personal effectiveness, and managers have been advised to develop and maintain guanxi with their staff members (Pearce, 1997). Studies have shown that building personal guanxi is a foundation for effective leadership (Hui \& Graen, 1997) even when managers and subordinates in the leader-member relationship come from different cultures (Chen \& 
Tjosvold, 2006). Personal guanxi is said to promote constructive controversy between expatriate managers and employees, and help the managers to become knowledgeable and confident in their leadership role; as a result they can provide Chinese employees with challenging assignments and encourage their success and promotion in foreign ventures in China (Chen \& Tjosvold, 2007).

\section{Similarities and differences between LMX and guanxi}

In addition to research in the West that has documented the value of the LMX theory (Graen \& Uhl-Bien, 1995; Gerstner \& Day, 1997; Dulebohn et al., 2011), the theory has also been found to be useful in the Chinese context (Hui et al., 1999). High-quality LMX relationships have been seen as a foundation for effective leadership, promoting successful interactions between Western managers and local Chinese employees (Chen \& Tjosvold, 2005). However, in spite of the usefulness of this theory, previous studies also confirm the difficulties of working across cultures (Hui \& Grean, 1997; Chen \& Tjosvold, 2005) due to different social values and norms. Exploring the similarities and differences between the Western notion of LMX and Chinese guanxi may be worthwhile to make Western managers more aware of what guanxi really means, and to help them overcome cultural obstacles and develop productive and harmonious interactions with local employees (Chen \& Chen, 2004; Ladkin, 2010).

\section{Similarities between LMX and guanxi}

Firstly, both LMX and guanxi are fundamentally embedded in the interpersonal relationships of two individuals (e.g. Dansereau et al. 1975; Hui et al., 1999; Fan, 2002), 
such as leader-member relationships. When the LMX theory was first introduced, one of the main reasons why it was so innovatory was that it describes how effective leadership relationships develop between dyadic 'partners' in and between organizations (Graen \& Uhl-Bien, 1995), and many studies on LMX are still working on this level. Likewise, dyadic ties with the leader are important to Chinese employees; guanxi is built upon multiple one-on-one relations between two parties, with the emphasis on the personal and dyadic nature of the relationships (Chen \& Chen, 2004). These highly particular relationships between two parties are considered to be fundamental units of Chinese guanxi networks (Fan, 2002; Huang \& Wang, 2011). Emphasizing to Western managers the dyadic and particular one-to-one relationship with subordinates, which comes up in both LMX and guanxi, can therefore help them to understand Chinese employees and work more effectively with them.

Secondly, the LMX theory is similar to guanxi in that both approaches stress that leader-member relationships develop gradually through interactions following the principle of reciprocity. In fact, work relationships are characterized by continuous and mutual interconnections between the parties (Ferris et al., 2009). These interconnections in social exchange relationships have been called "reciprocal interdependence" (Cropanzano \& Mitchell, 2005). The reciprocity principle makes the leadership relationship more social in nature. In a high LMX relationship, when leaders put extra effort into the relationship through for example clear support and contingent reward behaviour, followers are expected and encouraged to reciprocate by providing the leader with more than is basically required, in multiple ways (Dulebohn et al., 2011). Similarly with Chinese values: there too reciprocity occupies an important place in guanxi. 
Practices associated with guanxi in the work context involve the exchange of both feelings and material benefits, and these often occur between the leader and each of his or her followers (Yang, 2001). Acting against the principle of reciprocity is a clear sign of not wanting to pursue or maintain the relationship (Chen \& Chen, 2004).

Finally, both the LMX theory and guanxi highlight the importance of the quality of the relationship between the parties. Employees tend to respond favourably to managers who are willing to offer them inspiration and support (Judge \& Piccolo, 2004); in response employees will exert themselves to perform the roles assigned to them and they in turn will try to form a high LMX with their managers (Maslyn \& Uhl-Bien, 2001; Dulebohn et al., 2011). Previous LMX studies show that a high-quality relationship leads to more effective leadership and improves employees' performance dramatically (Scandura \& Graen, 1984; Graen \& Uhl-Bien, 1995). High-quality LMX relationships are obviously more desirable than low-quality relationships. A similar situation can also be found in guanxi. Personal guanxi develops on social occasions through the mutual exchange of both material goods and feelings (Bian \& Ang, 1997). Those with closer guanxi are more likely to get a higher level of trust and respect, and to generate a greater sense of obligation. When Western managers develop high-quality guanxi with employees, the local Chinese employees feel a strong bond. The importance of building up this kind of relationship must be clear (Pearce, 1997; Chen \& Tjosvold, 2007).

In general it seems that the LMX theory and guanxi have several features in common that provide the Western manager with a useful basis for successful leader-member relationships with local employees in China. However, besides the similarities there are also differences. Applying the ideas of LMX in the context of China 
can be challenging if some of the features peculiar to guanxi, which are not prominent in the LMX theory, are not taken into consideration.

\section{Differences between LMX and guanxi}

Guanxi is defined as personal ties between two individuals based on human feelings (Jacobs, 1979) - affection and a sense of mutual obligation (Thibaut \& Kelley, 1959). The former refers to the degree of emotional attachment and the willingness to take care of each other. The latter, on the other hand, is often described as a sense of indebtedness that results from social and economic exchanges (Chen \& Chen, 2004). Thus, in guanxi, relationships with associates who are considered close contain both a high level of affection (Chow \& Ng, 2004) and a strong sense of obligation. The feeling of concern can be a kind of exchange currency which affects the quality of the relationship between managers and subordinates (Law, 2010). This contrasts with the Western LMX approach, which is both transactional and transformational (Graen \& Uhl-Bien, 1995), in which the leader-member exchange relationship can only legitimately become an equity-matching relationship, where contribution and competence, not feelings, serve as the key components (Hui \& Graen, 1997; Chen et al., 2009). The role and importance of feelings are clearly underlined in the guanxi approach, so in order to take local social and moral values and norms into consideration, the Western manager has to recognise the value of a more personal, even a positively emotional, approach to her or his subordinates in the Chinese context.

Another important issue which must be taken into account is "face" and the sense of shame (Chueng \& King, 2004; Zhong, 2007). "Face" is defined as one's public image (Tsang, 1998). There is an old saying in China, "A person needs a face; a tree needs 
bark". In Chinese society, reputation is everything. When someone behaves inappropriately, it is generally unwise to admonish them directly in public. Evidence suggests that Chinese people favour compromise and use approaches that avoid open, face-to-face conflict, while westerners might prefer direct confrontation (Bond et al., 1985; Tse et al., 1994; Chen \& Tjosvold, 2007). If a Westerner makes a Chinese person embarrassed or causes them to lose face, the relationship cannot succeed because the shamed person cannot continue to communicate with dignity (Ho \& Redfern, 2010; Huang \& Wang, 2011).

In general, Chinese culture values individuals who have a sense of shame, one of the essential human emotions. The common saying, "A thick face without shame", or Confucius' saying, "Knowing shame will be close to being brave", all imply that the Chinese emphasize the sense of shame as a key factor in interpersonal relationships (Zhong, 2007). The expectation that one will always maintain face and avoid putting anyone in the position of feeling shame in front of a guanxi partner, and indeed in public generally, can be a challenge for Western managers, a cultural barrier that they have to try to overcome. Chinese communication is ambiguous, indirect and highly contextual. In conversation, the real meaning, especially if it is negative, is often implied rather than stated. In the event of a conflict arising, Chinese tend to believe that the truth will manifest itself through non-linear processes of discovery, using indirect and vague language and relying on the listener's ability to grasp the meaning. Westerners, in contrast, tend to emphasise logic and rationality, using a more direct and explicit way to ensure that the listener receives the exact message (Wang, 2008). Western managers working in China therefore have to learn how to express themselves tactfully and 
properly in an indirect and context-sensitive communication process if they want to apply the LMX theory there and build good leader-member relationships. In order to achieve the goals, all possible means should be engaged to facilitate the adjustment process. As suggested by Brewster (1995) and Aryee (1997), interaction skill training and careful selections of candidates for expatriate assignments who are most motivated to learn and voluntarily adapt themselves to the local business environment are being crucial for successful adjustment. Finding by Selmer et al. (1998) show that the post-arrival training has been promoted as an especially effective tool to facilitate international adjustment of expatriate managers.

\section{Ethical considerations}

Different types of guanxi have been identified, differing in nature, motivation and underlying values. Fan (2002) proposed a process model of three types: family guanxi, helper guanxi and business guanxi, which occur among family members, among familiar people involved in the exchange of favours, and through personal connections from business to business, respectively. Since family guanxi is generally beyond the context of the workplace, we focus here on Fan's other two types of guanxi. Bedford (2011) extended Fan's helper and business guanxi frameworks: he called them working guanxi, which stresses the processes of social exchange related to workplace goals, and backdoor guanxi, reflecting the process of negotiating business solutions through one's guanxi network, but also possibly involving corruption and social harm.

The ethical status of guanxi has caused much controversy. Westerners also need to know about these allegations of corruption (Tsang, 1998, p. 66) and social harm, 
particularly nepotism (Verhezen, 2008), which may pose ethical challenges in leadership relationships with Chinese subordinates.

A certain way of using guanxi may lead to corruption. Ambiguity is the very essence of guanxi relationships (Verhezen, 2008). Clearly "guanxi" is used for instrumental purposes (Smart, 1993), but when the emphasis in the "art of guanxi", which "lies in the skilful mobilization of moral and cultural imperatives such as obligation and reciprocity in pursuit of both diffuse social ends and calculated instrumental ends" (Yang 1989, p. 35) is only on material advantage, the exchange has to be classified as bribery (Yang, 1989, p.48; Smart, 1993). However, in practice the line between proper guanxi and bribery is often blurred. Take gift-giving, for example. Although the indicator of bribery is often taken to be the offer of money (Silin, 1972), and giving gifts can be a simple act of friendship and goodwill, Chinese bribe with gifts more often than with cash, and this sometimes makes it difficult to identify what is ethical and what is not.

Guanxi may transmute into nepotistic relationships. In China, the concept of guanxi involves social relationships or interconnections based upon reciprocal benefits (Yang, 1994), depending on the social context. Put another way, as a form of social capital - a network of individuals that may result in certain forms of capital and profit (Bourdieu, 1986) - guanxi focuses on reciprocal interest and helps its practitioners (Bian, 1994) to amass symbolic capital and benefits (Wong \& Tam, 2000). The more social, symbolic or economic capital and reciprocal benefits one has at one's disposal, the greater is one's socio-economic standing and influence. Networks of guanxi are usually characterized by 'general' or 'positive' reciprocity. Generating trust and increasing the value of the interaction facilitated by this kind of relationship are the main purposes of social 
networking (Standifird \& Marshall, 2000). However, if this positive guanxi is dominated by self-seeking opportunism, then an ethically justifiable guanxi network will easily become a negative, nepotistic guanxi based on power, rather than social norms and principles (Verhezen, 2008). This nepotistic guanxi makes it more likely that the person concerned will gain benefits and secure their own interests, and it discriminates against those who do not have it (Bian, 1994), thereby possibly lowering the procedural justice of impartial neutrality and negatively affecting 'generalized' trust (Chen et al, 2004), thus contravening the principle of impartial and fair systems.

This being the case, the expatriate Western manager needs to understand the thinking behind this more personal and less transactional approach to relationships and know how to use it properly and ethically. In particular, trying to identify the purpose and likely outcome of the pursuit of guanxi in any particular case would make sense to prevent unethical guanxi behaviour in the workplace. Forms of guanxi that are dominated by pure self-seeking opportunism may produce beneficial effects for only the main players, while harming others (Warren et al., 2004). In this sense, guanxi can have an unethical effect in a relationship. The Western manager also needs to try to understand the rules, so to speak, for local organisational bribery, in order to be able to distinguish between what is normal entertainment and what is bribery. Such an understanding would reduce the chances of his or her being involved in bribery or scandal and thereby save them from potentially unethical conduct.

\section{Discussion and conclusion}

In this paper the first aim was to analyze the similarities and differences between the LMX theory and the social and moral norms of guanxi. We think that for the Western 
expatriate manager, the best way to build an effective and sustainable leader-member relationship with local employees in China is to rely on the similarities of the two approaches. As shown in this paper, both approaches emphasise the dyadic and particular nature of the interpersonal relationship, so nurturing such relationships with Chinese employees is important.

Moreover, in both approaches the gradual development of an interdependent relationship through continuous and shared interactions following the principle of reciprocity is seen as crucial. The expatriate manager needs to remember the importance of the principle of reciprocity in her or his own leadership behaviour, and respect and encourage such behaviour from his or her subordinates. It is important for the manager to understand that such relationship development takes time.

Finally, a high-quality relationship including the dimensions of trust, obligation and respect is valued in both the LMX theory and guanxi. Managers must follow the basic principles of ethical and moral conduct at all times and in all places. When the behaviour, words and deeds of managers at all organisational levels are in line with common organisational values and norms, managers are perceived as honest and as credible models by their Chinese employees, and this further promotes the development of high-quality leader-member relationships (Cogliser et al., 2009).

However, there are also differences between the LMX approach and the social and moral norms of guanxi, as this study has shown. Given these differences, applying LMX in the Chinese context can be a challenging undertaking for an expatriate manager who does not fully understand the peculiar features of guanxi in leader-member relationships. Our study shows that the role of emotions is much more important in leader-member 
relationships according to guanxi than in the LMX theory. We therefore conclude that the Western expatriate manager needs to take the local norms seriously and emphasize the personal and emotional side of the relationship with Chinese staff more strongly than the LMX theory suggests.

This study indicates that the emotions have two roles in the relationship. Firstly, the emotional attachment between the manager and the employee is regarded as morally and socially appropriate according to guanxi, and so the manager's willingness and ability to show personal care for employees is crucial. Secondly, maintaining face, the manager's and the employee's public image (Tsang, 1998; Zhong, 2007), in their mutual relationship is an important moral norm in guanxi. This requires from the manager (as well as from employees) sensitivity in understanding the role of shame in the maintenance of face. If either side loses face, the quality of the leader-member relationship deteriorates. The communication style of the manager is a key factor in this. The expatriate manager needs to learn and apply a more context-dependent and indirect communication style with Chinese employees than he or she will typically use in Western contexts.

Although effective information sharing and communication between the manager and the employee are stressed in the LMX theory (Chen \& Tjosvold, 2007), the role of communication style is neither taken seriously nor articulated very clearly in the theory and there is no mention at all of a need to consider the social and moral context of the communication behaviour. We think that the topic could usefully be added to the theory, especially in view of the increasing globalization of businesses, which calls for increasing awareness of the contextual perspective of leadership communication and its importance 
in building successful workplaces.

Moreover, even though the LMX theory involves both transactional and transformational elements, the role of emotions is not deeply embedded and conceptualized in the theory. For development of the LMX theory it is important to know more about what happens in the space between leaders and followers to create the experience of the exchange (Ladkin, 2010, p. 56). This study suggests that the emotions of caring and shame play a crucial role in the space between the Western expatriate manager and Chinese employees in their relationships. In general, we think that the rather weak focus on emotions in the LMX theory may be a sign of a general tendency in Western organizational leadership approaches which, despite a gradual widening of interest in the emotions, have traditionally marginalized or even ignored altogether their role in both theory and practice (Fineman, 2000; Ashkanasy et al., 2002).

The second aim of this paper was to highlight and discuss ethical challenges related to guanxi which Western managers may face in their leader-member relationships, and for which they certainly need to be prepared, in the Chinese work context. As highlighted here, one possible problem for the Western manager is unethical conduct related to guanxi, such as corruption and nepotism. In order to use this more personal and less transactional guanxi approach properly and ethically, the Western manager first of all needs to maintain generally virtuous characteristics such as honesty and integrity, which are emphasized in many Western leadership theories (Yukl, 2010). Discussions on these issues can not only provide a foundation for constructive controversy but also improve understanding between Western and Chinese parties (Chen \& Tjosvold, 2006, 2007). 
To conclude, this study both serves as an aid for Western managers in China and also helps to reflect on how to integrate probably the best known relational leadership theory, the LMX framework (Ladkin, 2010), into the Chinese context. It is hoped that through this description of the relationship between LMX and guanxi, both Western managers and local Chinese employees will be better able to understand each other's values and social and moral norms, and learn from them.

\section{Research limitations and further research}

This research has some limitations. First of all, as we all know, China is the third largest country in the world in area and it has the largest population in the world; obviously there are cultural differences between the different parts of China. These cultural differences should be taken into consideration in future research on the subject. Secondly, and similarly, in this article we use the term "Western" and "Westerners" in general to contrast with China. However, we are aware that there are also cultural differences within Western countries. In the future, it would be fruitful to select one specific Western country for comparative studies.

Thirdly, although the description of the relationship between LMX and guanxi in this paper would provide Western managers and local Chinese employees with knowledge on how to understand better each other's values and social norms, in practice, however, what needs to be done by both groups to really learn from each other's culture still deserves our particular attention, which needs to be addressed in the future in order to make this conceptual paper more practical and useful. Another important topic for empirical research in the future is the ethical issues in Chinese guanxi, from both the 
Western and the Chinese viewpoints. Empirically investigating the association between business ethics and leader-member relationships is another topic worth researching in the future, as is the role of an ethical consciousness among organisational leaders and employees both in the West and East in the construction of a sustainable leader-member relationship. Finally, we suggest that the role of emotions in leader-member relationships requires further research.

\section{References}

Anand, S., Hu, J., Liden, R.C., and Vidyarthi, P.R.: 2011, 'Leader-member Exchange: Recent Research Findings and Prospects for the Future', SAGE Handbook of Leadership, Los Angeles, Sage, 311-325.

Aryee, S. (1997). Selection and Training of Expatriate Employees. In N.Anderson \& P. Herriot (Eds.), International handbook of selection and assessment, Chichester, UK: Wiley.of selection and appraisal London: Wiley, 147-160.

Aryee, S. and Chen, Z.X.: 2006, 'Leader-member Exchange in a Chinese Context: Antecedents, the Mediating Rrole of Psychological Empowerment and Outcomes. Journal of Business Research, 59, 793-801.

Ashkanasy, N.M., Zerbe, W.J. and Härtel. C.E.J.: 2002, 'Managing Emotions in a Changing Workplace', in N.M. Ashkanasy,W.J., Zerbe and Härtel, C.E.J. (eds.) Managing Emotions in the Workplace, Armonk, Sharpe, 3-22.

Bauer, T. N. and Green, S.: 1996, 'Development of Leader-member Exchange: A Longitudinal Test', Academy of Management Journal, 39 (6), 1538-1567.

Bedford, O.: 2011, 'Guanxi Building in the Workplace: A Dynamic Process Model of 
Working and Backdoor Guanxi', Journal of Business Ethics, 104 (1), 149-158.

Bian, Y.J., 1994, Work and inequality in urban China. 1st Edn., State University of New York Press, New York, ISBN-10: 0791418014, pp: 286.

Bian, Y. and Ang, S.: 1997, 'Guanxi Networks and Job Mobility in China and Singapore', Social Forces, 75: 981-1005.

Blau, P. M.: 1964, Exchange and Power in Social Life, New York: Wiley, pp. 94-99.

Bond, M. H., Wan, K. C., Leung K., and Giacalone, R. A.: 1985, 'How are Responses to Verbal Insult Related to Cultural Collectivism and Power Distance?', Journal of Cross-Cultural Psychology, 16, 111-127.

Bourdieu, P.:1986, 'The forms of Capital', in Richardson, J. (Ed), Handbook of Theory and Research for the Sociology of Education, New York, Greenwood Press.

Brewster, C.: 1995, Effective Expatriate Training. In J. Selmer, Expatriate Management: New Ideas for International Business Westport (CT): Quorum Books, 57-72.

Brower, H. H., Schoorman, F. D., and Tan, H. H.: 2000, 'A Model of Relational Leadership: The Integration of Trust and Leader-Member Exchange', The Leadership Quarterly, 11 (2), 227-250.

Chan, R. Y. K., Cheng, L. T. W. and Szeto, R. W. F.: 2002, 'The Dynamics of Guanzi and the Ethics of Chinese Executives', Journal of Business Ethics, 41(4), 327-336.

Chen, X. P. and Chen, C.C.: 2004, 'On the Intricacies of the Chinese Guanxi: A Process Model of Guanxi Development', Asia Pacific Journal of Management, 21, 305-324.

Chen, X. P., Eberly, M. B., Chiang, T., Farh, J., and Cheng. B.: 2011, 'Affective Trust in Chinese Leaders: Linking Paternalistic Leadership to Employee Performance', Journal of Management, DOI: 10.1177/0149206311410604. 
Chen, Y., Friedman, R., Yu, E., Fang, W., and Lu, X.: 2009, 'Developing a Three-Dimensional Model and Scale for Supervisor-Subordinate Guanxi', Management and Organizational Review, 5(3), 375-399.

Chen, Y. F. and Tjosvold, D.: 2005, 'Cross Cultural Leadership: Goal Interdependence and Leader-Member Relations in Foreign Ventures in China. Journal of International Management, 11, 417-439.

Chen, Y. F. and Tjosvold, D.: 2006. 'Participative Leadership by Western Managers in China: The Role of Relationships', Journal of Management Studies, 43(8), 1727-1752. Chen, Y. F. and Tjosvold, D.: 2007, 'Guanxi and Leader Member Relationships between American Managers and Chinese Employees: Open-minded Dialogue as Mediator', Asia Pacific Journal of Management, 24, 171-189.

Chow, I. H. S. and Ng, I.: 2004, 'The Characteristics of Chinese Personal Ties (guanxi): Evidence from Hong Kong', Organization Studies, 25(7), 1075-1093.

Chueng, T.S. and King, A.Y.: 2004, 'Righteousness and Profitableness: The Moral Choices of Contemporary Confucian Entrepreneurs', Journal of Business Ethics, 54, 254-260.

Ciulla, J.B.: 2008, 'Leadership Studies and the “fusion of horizons', Leadership Quarterly, 19(4), 939-935.

Cogliser, C.C., Schiriesheim, C.A., Scandura, T.A., and Gardner, W. L.: 2009, 'Balance in Leader and Follower Perceptions of Leader-member Exchange: Relationships with Performance and Work Attitudes'. Leadership Quarterly, 20, 452-465.

Cropanzano, R., and Mitchell, M. S.: 2005, 'Social Exchange Theory: An Interdisciplinary Review', Journal of Management, 31, 874-900. 
Dansereau, F. Jr, Graen, G. and Haga, W.J.: 1975, ‘A Vertical Dyad Linkage Approach to Leadership within Formal Organisations: A Longitudinal Investigation of the Role Making Process', Organisational Behaviour and Human Performance, 13, 46-78.

Dienesch, R and Liden, R.: 1986, 'Leader-member Exchange Model of Leadership: A Critique and Further Development', The Academy of Management Review, 11 (3), 618-664.

Dorfman, P. W., Howell, J. P., Hibino, S., Lee, J. K., Tate, U., \& Bautista, A.: 1997, 'Leadership in Western and Asian countries: Commonalities and differences in effective leadership processes across cultures'. Leadership Quarterly, 8 (3), 233-274.

Dulebohn, J. H., Bommer, W. H., Liden, R. C., Brouer, R., and Ferris, G. R.: 2011, 'A Meta-Analysis of the Antecedents and Consequences of Leader-member Exchange: Integrating the Past with an Eye toward the Future', Journal of Management, DOI: 10.1177/0149206311415280.

Dunfee, T. W., and Warren, D. E.: 2001, 'Is Guanxi Ethical? A Normative Analysis of Doing Business in China', Journal of Business Ethics, 32(3), 191-204.

Erdogan, B., Kraimer, M. and Liden, R.C.: 2002, 'Person-organisation Fit and Work Attitudes: The Moderating Role of Leader-Member Exchange', Academy of Management Proceedings, 65-114.

Fan, Y.: 2002, 'Guanxi's Consequences: Personal Gains at Social Cost', Journal of Business Ethics, 38, 371-380.

Ferris, G. R., Liden, R. C., Munyon, T. P., Summers, J. K., Basik, K. J., and Buckley, M. R.: 2009, 'Relationships at Work: Toward a Multidimensional Conceptualisation of Dyadic Work Relationships', Journal of Management, 35, 1379-1403. 
Fineman, S. (Dd.): 2000, Emotion in Organizations (Vol. 2). London: Sage.

Gerstner, C and Day, D.: 1997, 'Meta-Analytic Review of Leader-member Exchange Theory: Correlates and Construct Issues', Journal of Applied Psychology, 82 (6), 827-844.

Gouldner, Alvin W.: 1960, 'The Norm of Reciprocity: A Preliminary Statement', American Sociological Review, 25 (2), 161-178.

Graen, G.: 1976, Role-Making Processes within Complex Organisations. In M. D. Dunnette (Ed.), Handbook of industrial and organisational psychology, Chicago: Rand McNally, pp. 1201-1245.

Graen, G and Scandura, T.: 1987, 'Toward a Psychology of Dyadic Organising', In Cummings, L and Staw, B (Dds), Research in Organisational Behaviour, 9, 175-208.

Graen, G. and Uhl-Bien, M.: 1991, 'The Transformation of Work Group Professionals into Self-managing and Partially Self-designing Contributors: Toward a Theory of Leadership-Making', Journal of Management Systems, 3 (3), 33-48.

Graen, G. and Uhl-Bien, M.: 1995, 'Relationship-based Approach to Leadership: Development of Leader-member Exchange (LMX) Theory of Leadership over 25 Years: Applying a Multi-level Multi-Domain Perspective', Leadership Quarterly, 6 (2), 219-247.

Hackley, C. A. and Dong, Q.: 2001, 'America Public Relations and China's Guanxi', Public Relations Quarterly, 46, 16-19.

Ho, C. and K. Redfern: 2010, 'Consideration of the Role of Guanxi in the Ethical Judgments of Chinese Managers', Journal of Business Ethics, 96: 207-221.

Hofstede, G.: 1980, Culture’s Consequences: International Differences in Work-related 
Values, Beverly Hills, CA: sage.

Hsu, F.L.K.: 1982, American and Chinese: Passage to differences. Honolulu: University of Hawaii Press.

Hui, C. and Graen, G.: 1997, 'Guanxi and Professional Leadership in Contemporary Sino-American Joints Ventures in Mainland China', Leadership Quarterly, 8, 451-465.

Hui, C., Law, K.S and Chen, Z.: 1999, 'A structural Equation Model of the Effects of Negative Affectivity, Leader-member Exchange, and Perceived Job Mobility on In-role and Extra-role Performance: A Chinese Case', Organisational Behaviour and Human Decision Processes, 77 (1), 3-21.

Huang, K.P. and Wang, K.Y.: 2011, 'How Guanxi Relates to Social Capital? A Psychological Perspective', Journal of Social Science, 7 (2), 120-126.

Hwang, K. K.: 2000, 'Chinese Relationism: Theoretical Construction and Methodological Considerations', Journal for the Theory of Social Behaviour, 30, $155-178$.

Hwang, K. K.: 2008, 'Leadership Theory of Legalism and its Function in Confucian Society. In C. C. Chen, and Y. T. Lee (Eds.), Leadership and Management in China: philosophies, theories and practices. Cambridge University Press, pp.108-142.

Jacobs, J. B.: 1979, 'A preliminary Model of Particularistic Ties in Chinese Political Alliances: Kan-ching and Kuan-his in a Rural Taiwanese Township'. China Quarterly, 78, 237-273.

Judge, T. A., and Piccolo, R. F.: 2004, 'Transformational and Transactional Leadership: A Meta-analytic Test of Their Relative Validity', Journal of Applied Psychology, 89, 755-768. 
Ladkin, D: 2010, Rethinking Leadership. A New Look at Old Questions, Edward Elgar, Cheltenham.

Law, K. S., Wang, and Hui.: 2010, 'Currencies of Exchange and Global LMX: How They Affect Employee Task Performance and Extra-role Performance', Asia Pacific Journal Management, 27, 625-646.

Liden, R. C. and Maslyn, J.: 1998, 'Multidimensionality of Leader-member Exchange: an Empirical Assessment through Scale Development', Journal of Management, 24, 43-72.

Liden, R.C., Sparrowe, R.T., and Wayne, S.J.: 1997, 'Leader-member Exchange Theory: The Past and Potential for the Future', In G. Ferris (Ed.), Research in personnel and human resources management, 15, 47-119.

Lovett, S., L. C. Simmons, and R. Kali: 1999, 'Guanxi versus the Market: Ethics and Efficiency', Journal of International Business Studies 30(2), 231.

Maslyn, J. M., and Uhl-Bien, M.: 2001, 'Leader-member Exchange and Its Dimensions: Effects of Self-effort and other's Effort on Relationship Quality', Journal of Applied Psychology, 86, 697-708.

Pearce, R. J.: 1997, 'Towards Understanding Joint Venture Performance and Survival: A Bargaining and Influence Approach to Transaction Cost Theory', Academy of Management Review, 22, 203-235.

Peng, M. W., Lu, Y., Shenkar, O., and Wang, D. Y.L.: 2001, 'Treasures in the China House A Review of Management and Organisational Research on Greater China', Journal of Business Research, 52, 95-110.

Redding, S. Gordon and Wong, Gilbert Y.Y.: 1986, 'The Psychology of Chinese 
Organizational Behaviour', in Michael Harris Bond (ed.) The Psychology of the Chinese People, pp. 267-295. Oxford: Oxford University Press.

Scandura, T., \& Graen, G.B.: 1984, 'Moderating Effects of Initial Leader-member Exchange Status on the Effects of a Leadership Intervention, Journal of Applied Psychology, 69, 428-436.

Selmer, J., Torbio“rn, I., and De Leon, C. T.: 1998, 'Sequential Cross-cultural Training for Expatriate Business Managers: Pre-departure and Post-arrival', International Journal of Human Resource Management, 9(5), 831-840.

Silin, R.: 1972, 'Marketing and Credit in a Hong Kong Wholesale Market', In Economic Organization in Chinese Society. William Willmot, ed. 327-352. Stanford: Stanford University Press.

Sin, Nahrgang, J. D., and Morgeson, F. P.: 2009, 'Understanding Why They Don't See Eye to Eye: An Examination of Leader-member Exchange (LMX) Agreement', Journal of Applied Psychology, 94 (4), 1048-1057.

Smart, A.: 1993, 'Gifts, Bribes, and Guanxi: a Reconsideration of Bourdieu's Social Capital', Cultural Anthropology, 8 (3), 388-408.

Smith, P. B., and Peterson, M. F.: 1988, Leadership, Organizations and Culture: An Event Management Model, Beverly Hills, CA: Sage.

Solomon, R., Surprenant, C., Czepiel. J., and Gutman. E.: 1985, 'A Role Theory Perspective on Dyadic Interactions: The Service Encounter', Journal of Marketing, 99-111.

Sparrowe, R. and Liden, R. C.: 1997, 'Process and Structure in Leader-member Exchange', Academy of Management Journal, 22 (2), 522-552. 
Standifird, S.S. and R.S. Marshall: 2000, 'The Transaction Cost Advantage of Guanxibased Business Practices', Journal of World Business, 35, 21-42.

Su, C., Joe S., and Littlefield, J. E.: 2003, 'Is Guanxi Orientation Bad, Ethically Speaking? A Study of Chinese Enterprises', Journal of Business, 44, 303-312.

The Economist Intelligence Unit Limited: 1996. 'Selling China Postings to Managers: The Reluctant Expat', Business China.

Thibaut, J.W. and Kelley, H.H.: Interpersonal Relations: A Theory of Interdependence, Wiley, New York, 1959.

Tong, C. and Yong, P.: 1998, 'Guanxi Bases, Xinyong and Chinese Business Networks', British Journal of Sociology, 49(1), 75-96.

Tsang, Eric W. K.: 1998, 'Can Guanxi be a Source of Sustained Competitive Advantage for Doing Business in China?', Academy of Management Executive 12(2), 64-73.

Tse, D. K., Francis, J., and Walls, J.: 1994, 'Cultural Differences in Conducting Intra- and Inter-Cultural Negotiations: A Sino-Canadian Comparison', Journal of International Business Studies, 24, 537-555.

Tsui, A. S. and Farh, J. L.: 1997, 'Where Guanxi Matters: Relational Demography and Guanxi in the Chinese Context', Work and Occupations 24 (1), 56-79.

Uhl-Bien, M.: 2006, 'Relational Leadership Theory: Exploring the Social Processes of Leadership and Organising', The Leadership Quarterly, 17, 654-676.

Uhl-Bien, M., and Maslyn, J.M.: 2003, 'Reciprocity in Manager-subordinate Relationship: Components, Configurations and Outcomes', Journal of Management, 24,511-532. Verhezen, P.: 2008, 'Guanxi: Networks or Nepotism?', in Zsolnai, Laszlo (Ed), Europe-Asia Dialogue on Business Spirituality, Antwerp; Apeldoorn, Garant, pp. 
89-106.

Walumbwa, F.O., Cropanzano, R., and Goldman, B.M.: 2011, 'How Leader-Member Exchange Influences Effective Work Behaviors: Social Exchange and Internal-External Efficacy Perspectives', Personnel Psychology, 64(3), 739-770.

Wang, J.: 2008, 'A Cross-cultural Study of Daily Communication between Chinese and American-- From the Perspective of High Context and Low Context', Asian Social Science, 4 (10), 151-154.

Wang, Z.M. and Heller, F.A.: 1993, 'Patterns of Power Distribution in Managerial Decision Making in Chinese and British Enterprises', International Journal of Human Resource Management, 4 (1), 113-128.

Warren, D. E., Dunfee, T. W., and Li, N.: 2004, 'Social Exchange in China: The Double-edged Sword of Guanxi', Journal of Business Ethics, 55, 355-372.

Wayne, S. J., and Green, S. A.: 1993, 'The Effects of Leader-member Exchange on Employee Citizenship and Impression Management Behaviour', Human Relations, 46, $1431-1440$.

Wong, Y.H. and Tam, J.L.M.: 2000, 'Mapping Relationships in China: Guanxi Dynamic Approach', Journal of Business and Industrial Marketing, 15 (1), 57-73.

Wu, J., Hom, P., Tetrick, L., Shore, L., Jia, L., Li, C., et al.: 2006, 'The Norm of Reciprocity: Scale Development and Validation in the Chinese Context', Management and Organisation Review, 2, 377-402.

Xin, K. R. and Pearce, J. L..: 1996, “Guanxi: Connections as Substitutes for Formal Institutional Support', Academy of Management Journal, 39, 1461-1568.

Xu, E., Huang, Huang, X., Lam, C. K., and Miao, Q.: 2011, 'Abusive Supervision and 
Work Behaviours: The Mediating Role of LMX', Journal of Organisational Behaviour, 33, 531-543.

Yang, K. S.: 1993, 'Chinese Social Orientation: An Integrative Analysis', In L. Y. Cheng, F. M. C. Cheung \& C. N. Cheng (Eds.), Psychotherapy for the Chinese, 19-56.

Yang, M.: 1989, 'The Gift Economy and State Power in China', Comparative Studies in Society and History, 31, 25-54.

Yang, M.: 1994, Gifts, favors and banquets: The art of social relationships in China. 1st Edn, Cornell University Press, pp. 370.

Yang, Y.: 2001, 'People on One's Own Side: A Case Study on the Typology of Chinese Guanxi', In C.-F. Yang (Ed.), Interpersonal Relationship, Affection and Trust of the Chinese: From an Interactional Perspective, 131-157.

Yeung, Irene Y. M. and Rosalie L. Tung: 1996, 'Achieving Business Success in Confucian Societies: The Importance of Guanxi (Connections)', Organization Dynamics, 25(2), 54-66.

Yukl, G.: 2010, Leadership in Organisations, Upper Saddle River, Prentice-Hall.

Zhong, C.: 2007, 'Application of Proverbs in Psychotherapy for the Chinese', World Cultural Research Review, 16-19. 